\title{
An Analysis of Oilseeds and Pulses Scenario in Eastern India during 2050-51
}

\author{
Anil Kumar Singh, Manibhushan, BP Bhatt, KM Singh \& Ashutosh Upaadhaya \\ ${ }^{1}$ Division of land and water management, ICAR RCER, Patna, India \\ Correspondence: Anil Kumar Singh, Division of land and water management, ICAR RCER, Patna, India. E-mail: \\ anil.icarpat@gmail.com
}

Received: August21, 2012Accepted: September3, 2012Online Published: December 13, 2012

doi:10.5539/jas.v5n1p241

URL: http://dx.doi.org/10.5539/jas.v5n1p241

\begin{abstract}
India is no longer dependent on other land produce especially with respect to food grains, thanks goes to policy planner researcher and the most to our farmers who make this dream to happen in our life time. We have to have worked hard systematically to prove our credential with regards to oilseeds and pulses. India is the world leader in production, consumption and import as well in case of pulses and not for behind in vegetable oils. India imports 2-3 Mt of pulses on regular basis and 9.2 Mt of vegetable oils during 2010-11.Currently India is in the mid-way of self-sustaining in oilseeds and pulses production. By the 2050, India as a whole will be able to sustain their production. Indian will produced plenty with respect to both the non-food commodity i.e. oilseeds and pulses. India may emerged as net exporter from being net importer for century the with respect to oilseed, and most probably for pulses also. Keeping in mind the socio-political situation and poor land to man ratio in eastern region the likelihood for oilseeds and pulses is not at all in bad shape.Inclusion of soybean and summer sesamum as oilseeds crop, nonconventional legume like faba bean and cowpea and summer mungbean in irrigated condition, cropping system approach especially intercropping are one of few options for horizontal expansion coupled with several technologies niche for vertical acceleration of production and productivity.
\end{abstract}

Keywords: climate change, eastern India, oilseeds, pulses, 2050, production, predictions, technology

\section{Introduction}

The eastern India share $22.5 \%$ of the country's geographical area and $33.64 \%$ of the country's population is residing in this part of India. Based on 2011 Indian decadal Census, region is residence of 407.4 million people with $71.84 \mathrm{~m}$ ha area. Eastern Indian region (Figure 1) includes plains of Assam, Bihar, Chhattisgarh, eastern Uttar Pradesh, Jharkhand, Odisha and West Bengal (Singh et al., 2011). Though the eastern region is endowed with natural resources, this region is one of the high populated regions in India and more than $80 \%$ population is rural, bound to accommodate about $69 \%$ farmers as marginal ( $<1.0$ ha land holding) (Chand, 2009). Small and fragmented landholdings limit, by and large, the adoption of latest farming practices. Not only has this region had about 7.5 million ha area under acidic soils. Likewise, sodic soils occupy an area of 3.81 million ha. This is enough to narrate the story that the eastern region is inhabited by resource poor people with small land: human ratio (Singh et al., 2011). Further, physiographically, the region hasgreat diversity and enjoys 3 distinct landscapes namely (i) plains of eastern UP, Bihar, West Bengal, and Assam; (ii) hilly and plateau regions in eastern UP, Bihar, Jharkhand, West Bengal, Odisha, Chhattisgarh, and Assam; and (iii) coastal plains of West Bengal and Odisha. Off course climate of the region is tropical, hot and humid except in hilly areas with high rainfall. The average annual rainfall varies from $1025 \mathrm{~mm}$ to $2823 \mathrm{~mm}$ (Singh et al., 2011; Singh et al., 2012a).

The forecasted deviations in agro-climatic conditions especially temperature and their connected impacts on rainfall and resulting accessibility of water to crops and extreme weather circumstances are all probable to interrupt substantially the potential of oilseeds as well as pulse production. The furthermost upsetting portion of the forecast is the estimated increase in wintertime and summertime temperatures by $3.2^{\circ} \mathrm{C}$ and $2.2^{\circ} \mathrm{C}$ respectively, by 2050 . Such uncharacteristic rises drives surely have an adverse impact on oilseedsand pulse production in the form of a reduction in total crop-cycle duration. Most of the oilseeds (Rape seeds \& mustard and sesamum) and most importantly pulses like mungbean and urdbean are short-duration crops (65-75 days). Further reduction in crop duration will amount to a lower yield per unit area (Singh et al., 2012a). Since region is inhabitant of poor's among the poor, food grain production is still a main task to feed the ever-increasing population and literally less 
area has been left for production of both non-food crop and very little scope exists for its horizontal expansion, prominent to vertical expansion with improved technology. However inclusion of summer pulse/legumes particularly short duration mungbean and promotion of summer oilseed like sesamum under irrigated condition. Sunflower and soybean also present better option in due course of time due it thermo and photosensitivity as compare to other crop. Summer groundnut is also having good potential waiting to explore its possibilities in this region (Chand \& Singh, 2012). Inclusion of oilseeds and pulses in cropping system as intercrop particularly crop with wide space like sorghum, maize sugarcane etc. will certainly instruments stability in respect to oilseeds and especially pulses production and will bound to prosperity in this region.

For a health person daily fat requirement of $29 \mathrm{~g}$ per day $(10.585 \mathrm{~kg}$ per person per year) is adequate to meet the physiological needs. It is desirable to intake less than 30 per cent of the total calorie from fats (NarasingaRao, 2010). Excessive intake of fats, especially saturated fats, adversely affects the lipid profile and increases the risk of cardiovascular diseases. Fat is an indispensable constituent of the nutrition, which offers energy and essential fatty acids to meet the body's metabolic necessities and enables the absorption of fat-soluble vitamins. Pulses are the basic ingredient in the diets of a vast majority of the Indian population, as they provide a perfect mix of vegetarian protein component of high biological value when supplemented with cereals. Pulses are not only important sources of proteins but also offer vitamins and minerals, popularly known as "Poor man's meat" and "rich men vegetable". For an active normal body pulses requirement is about $40 \mathrm{~g}$ per day or $14.6 \mathrm{~kg}$ per person per year (NarasingaRao, 2010). Data presented in table 1 clearly indicated that availability and intake of vegetable oils increased year on years which was $3.0 \mathrm{~kg}$ per person per year during 1950-51 and increased to $14.6 \mathrm{~kg}$ during 2010-11. Pulses availability decrease with the period of time, which was $60.5 \mathrm{~g} /$ day during 1950-51 and 31.6 g during 2010-11 (GoI, 2012).

Table 1.Per capita consumption of vegetable oil and pulses

\begin{tabular}{cccccc}
\hline \multirow{2}{*}{ Year } & \multicolumn{2}{c}{ Vegetable Oil } & & \multicolumn{2}{c}{ Pulses } \\
\cline { 2 - 3 } \cline { 5 - 6 } & kg/year & g/day & & kg/year & g/day \\
\hline $1950-51$ & 3.0 & 8.2 & & 22.1 & 60.5 \\
$1960-61$ & 4.0 & 11.0 & & 25.2 & 69.0 \\
$1970-71$ & 4.5 & 12.3 & & 18.9 & 51.9 \\
$1980-81$ & 5.0 & 13.7 & & 11.3 & 30.9 \\
$1990-91$ & 6.5 & 17.8 & & 15.2 & 41.6 \\
$2000-01$ & 9.5 & 26.0 & & 11.6 & 31.8 \\
$2010-11$ & 14.6 & 40.0 & & 11.5 & 31.6 \\
\hline
\end{tabular}

Sources: Economic Survey 2011-12 and www.Indiastat.com/Ministry of Agriculture, Govt. of India.

\section{Materials and Methods}

Procedure adopted to estimate population and their annual requirements with respect to oilseeds (vegetable oil) and pulses, why 2050-51 has been taken in to account for projections of both the non-cereals non-food items. We have taken in to account the data for the year 2010-11. Growth of each indices viz., area production and productivity has been worked out on yearly basis based on data available from 1950-51 to 2010-11. Expansion in the area is not taken as usual due to constrains, population pressure utilized for other commodity. Productivity has been taken in to account due to technological breakthrough and adoption of modern techniques and good agronomic practices. An effort has been made to obtain correct data so Government agency data has been taken in to account for area production, productivity as well as procurement of both the commodity.

\subsection{Procedure to Estimate Projections for Eastern India}

As per Indian Council of Agricultural Research, New Delhi, classification, Eastern Region of India, confined to seven states (Figure 1) which includes, all the district of Assam, Bihar, Chhattisgarh, Jharkhand, Odisha and West Bengal, and 27 eastern districts Uttar Pradesh, located in mid high rainfall zone of India (Singh et al., 2011). To estimate and to project, about the eastern region above geographical area was taken in to account. Population for the year 2010-11 was taken from the Census 2011 report for region and India as well, and based on that extrapolation for 2050 has been systematically carried out (Chand \& Singh, 2012). Projected population for 2050 
is now availableglobally, nationwide to district wise. Projected area expansion is based on land use pattern of the region and possibility and opportunity of uncultivated/waste/degraded land to bring out under cultivation in due course of time in a stipulated manner. Vegetable oils and pulses requirement for and adult are based recommended by NarasingaRao (2010) of National Institute of Nutrition, Hyderabad, which are $10.585 \mathrm{~kg}$ and $14.60 \mathrm{~kg}$ per person for vegetable oils and pulses per year on normative requirement. Corresponding oilseeds required to produce oils is 3.33 times of oils, assuming 33.3 per cent recovery across the oilseed produced in the eastern region (GoI, 2012).

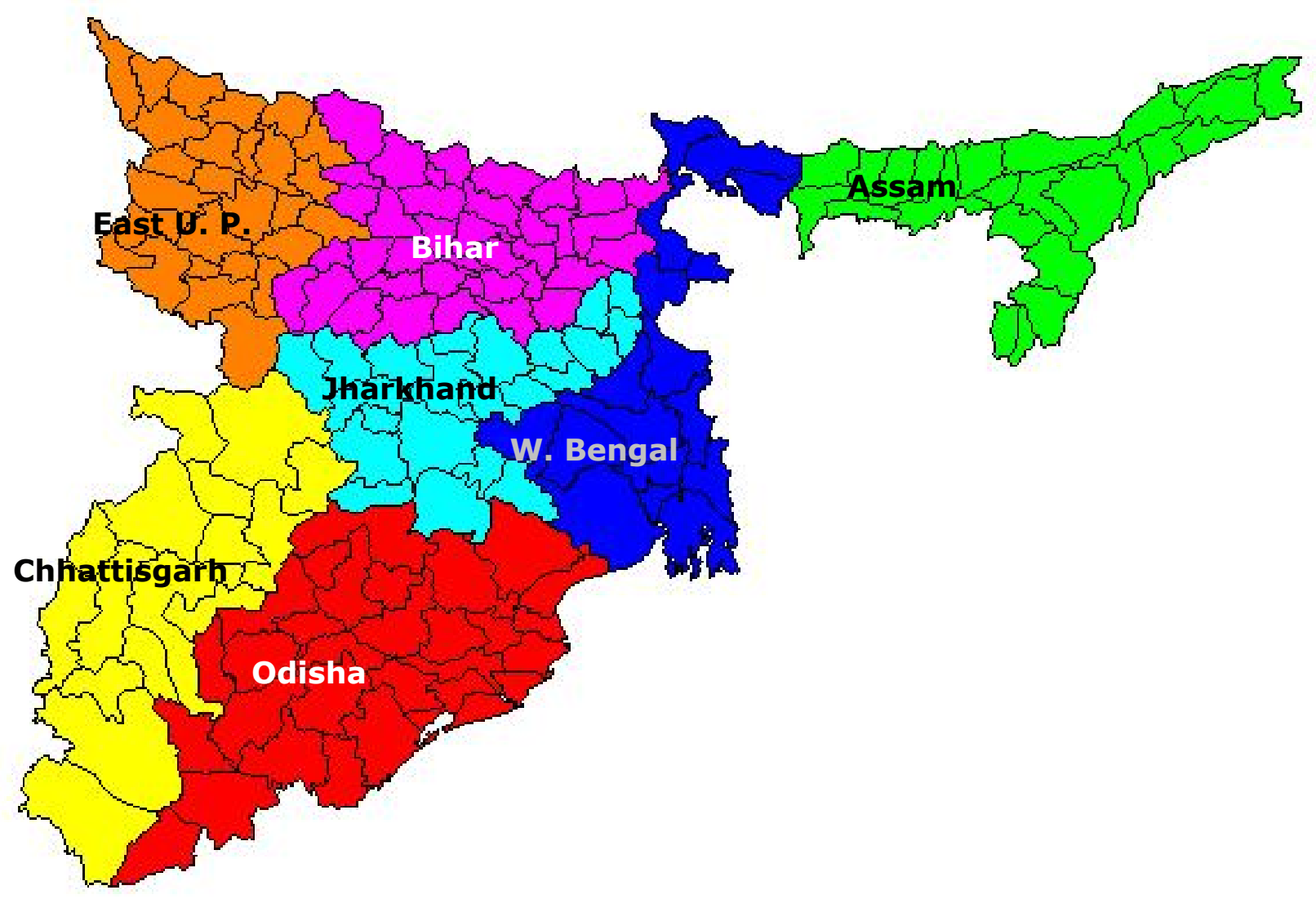

Fig. 1 Geographical spread of Eastern India

\subsection{Why the Year2050-51?}

As per the approximation of United Nation Organization, towards the year 2050, the world population is projected to stabilize at around 9.2 billion and Indian contribution to this effect is around 1.68 billion. According to another study conducted by US banking group Citi, Indian populationwill be stabilized sometime after 2035, and will reaches a plateau of just over 1.68 billion and starts ageing (Chand \& Singh, 2012). Moreover, fertility rates of city and rural Indian females will decline from presently 2.6 to 1.7 , which is when a country's birth and death rates make even. As a consequences of this India will never surpass it population to 1.7 billion benchmarks. Further, during 2050, Indian will be super economy in terms of purchasing power parity (PPP), with $\$ 85.97$ trillion leaving China, in second place (\$80.02 trillion) and the US \$ (39.07 trillion). These two points were taken in to account to project the scenario for the year 2050.

\subsection{Current Scenario (Based on 2010-11)}

Both commodities are hard foreign cash consuming to fulfil the Indian nutritional requirements. Since republic (1950) productivity of pulses and oilseeds has been increased by 0.56 and 1.41 times respectively. The compound rate of oilseed and pulses has been presented in table 2. Oilseeds outperformed as compared to pulses in all the growth indices since 1950-51, leading to India as a largest producer, importer and consumer of pulses. (Chand \& Singh, 2012; GoI, 2012). Though vegetable oils are not lagging behind, it's only attributed by change in diet 
patterns of Indian across the section. Courtesy to both the non-food commodity, India imports 2.5-3.5 Mt pulses every year on regular basis, whereas import bill for vegetable oils zoom to about $9.2 \mathrm{Mt}$ of vegetable oils during 2010-11 (Reddy, 2009; Hegde, 2012). Eastern region is one of the most deficit regions in the production of vegetable oil and pulses as compared to western, southern and northern region in this regard, obviously due over dominated by rice-wheat cropping system to provide food grains, very essential required carbohydrate (Singh et al., 2011).

Table 2. Compound growth rate achieved in pulses and oilseeds production in India during the period 1950-2011

\begin{tabular}{lcc}
\hline Particular & Oilseeds & Pulses \\
\hline Productivity during $1950(\mathrm{~kg} / \mathrm{ha})$ & 481 & 441 \\
Productivity during $2011(\mathrm{~kg} / \mathrm{ha})$ & 1159 & 689 \\
Growth (\%) & 1.41 & 0.56 \\
Overall compound growth rate (\%) & 1.455 & 1.011 \\
Compound growth rate (\%) Area & 1.57 & 0.52 \\
Compound growth rate (\%) Production & 3.0 & 1.27 \\
Compound growth rate (\%) Productivity & 1.42 & 0.73
\end{tabular}

Source: Department of Agriculture and Cooperation, Ministry of Agriculture, Govt. of India

\section{Results and Discussions}

Based on the calculation/estimation projection has been worked out for oilseeds and pulses for the eastern India and were compared with All Indian level for total as union of India.First of all projections for oilseeds were discussed and followed by pulses.

\subsection{Oilseeds}

The present scenario (2010-11) with regards to oilseed a major non-food commodity are presented in table 3 and 4 , clearly indicate about the present grim situation, especially with reference to eastern region and India as a wholeas well (Chand \& Singh, 2012;GoI, 2012). This region produced very less what the region consumed, and is major shareholder of Indian produce and import. The region is endowed with dense population and full of potential to improve its productivity in both the commodity, which will gradually realize its potential in due course of time as discussed in this article at appropriate place. For the sake of continence we will discuss first oil seeds and later on pulses (Hegde, 2012).

Table 3. All-India area, production and productivity of nine oilseeds

\begin{tabular}{cccc}
\hline Year & Area (Mha) & Production $(\mathrm{Mt})$ & Productivity $(\mathrm{Kg} / \mathrm{ha})$ \\
\hline $1950-51$ & 10.73 & 5.16 & 481 \\
$1960-61$ & 13.77 & 6.98 & 507 \\
$1970-71$ & 16.64 & 9.63 & 579 \\
$1980-81$ & 17.60 & 9.37 & 532 \\
$1990-91$ & 25.89 & 18.60 & 719 \\
$2000-01$ & 22.77 & 18.44 & 810 \\
$2010-11 *$ & 26.82 & 31.10 & 1159 \\
\hline
\end{tabular}

* Fourth Advance Estimates

Source: Department of Agriculture and Cooperation, Ministry of Agriculture, Govt. of India

Decadal interval data has been presented in table 3 with respect to nine oilseeds crop provides glimpses of success story of pulses production since 1950-51. All the three success indicator viz., area production and productivity were registers incremental growth with the time at all India levels, though some disturbances were also seen in all 
the growth indicators. Maximum area (26.82 Mha) under oilseed was recorded during 2010-11 only (GoI, 2012). We are self-sufficient if considered ideal dietary requirements. Bad food habit force government to import edible vegetable oils. This glowing depiction is for India as whole. During 2010-11, at eastern region level area production, productivity, requirements and need for import from other states were presented in table 4 . The calculation is based on standard vegetable oils requirements i.e. $10.585 \mathrm{~kg}$ per person/year which is equivalent to $35.25 \mathrm{~kg}$ oilseeds, assuming 33 per cent oil recovery in general (NarasingaRao, 2010). During the financial year 2010-11, region produced 1.67 Mt oilseeds from 2.03 Mha with productivity of $823.9 \mathrm{~kg}$ /ha well below the National average $(1159 \mathrm{~kg} / \mathrm{ha}$ ) leading to purchase/ import $12.69 \mathrm{Mt}$. India imported only 10.32Mt, means total import plus 3.12 Mt internal supply were arranged for this region only. The Indian import is solely blame to this region only as presented in table 4 (GoI, 2012).Eastern region performances in oil seeds production is liability for Indian vegetable oils sector perforamance (Hegde, 2009).

Table 4. Oilseeds area, production, productivity and import status in eastern India during 2010-11

\begin{tabular}{lcccccc}
\hline States & Population (M) & Area (Mha) & Production (Mt) & Productivity (kg/ha) & Requirement (Mt) & $\begin{array}{c}\text { Import } \\
\text { (Mt) }\end{array}$ \\
\hline Assam & 31.1 & 0.28 & 0.14 & 500 & 1.1 & 0.96 \\
Bihar & 103.8 & 0.14 & 0.14 & 1000 & 3.66 & 3.52 \\
Chhattisgarh & 25.5 & 0.1 & 0.08 & 800 & 0.9 & 0.82 \\
East Uttar Pradesh & 80.9 & 0.58 & 0.41 & 706.9 & 2.85 & 2.44 \\
Jharkhand & 32.9 & 0.007 & 0.0054 & 771.4 & 1.16 & 1.15 \\
Odisha & 41.9 & 0.29 & 0.17 & 586.2 & 1.48 & 1.31 \\
West Bengal & 91.3 & 0.63 & 0.73 & 1158.7 & 3.22 & 2.49 \\
Eastern India & 407.4 & 2.03 & 1.67 & 823.9 & 14.36 & 12.69 \\
\hline All India & 1175 & 26.82 & 31.1 & 1159 & 41.42 & 10.32 \\
\hline
\end{tabular}

Source: Department of Agriculture and Cooperation, Ministry of Agriculture, Govt. of India

\subsection{Decadal Growth Expected in Oil Seeds (2010-11 to 2050-51)}

Expected in scenario of decadal growth in oilseeds sector were presented in table 5. In this table data were given only for productivity, obviously because of not much scope of horizontal development (increase in area) is exist especially for this region i.e. eastern India. Since, only vertical growth has to be happened due to technological breakthrough only productivity scenario has been forecasted for individual states as well as eastern India as whole (GoI, 2012; Singh et al., 2012; Hegde, 2012). During 2050-51, Bihar will be the leader productivity term $(1708.8 \mathrm{~kg} / \mathrm{ha})$. Assam will be the laggard one with less than a ton productivity $(854.4 \mathrm{~kg} / \mathrm{ha})$.

Table. 5 Projected decadal growth in oil seeds productivity $(\mathrm{kg} / \mathrm{ha})$ in eastern India

\begin{tabular}{lccccc}
\hline \multirow{2}{*}{ Years } & \multicolumn{5}{c}{ Oil seeds productivity (kg/ha) } \\
\cline { 2 - 6 } & $2010-11$ & $2020-21$ & $2030-31$ & $2040-41$ & $2050-51$ \\
\hline Assam & 500.0 & 559.7 & 653.6 & 752.6 & 854.4 \\
Bihar & 1000.0 & 1119.4 & 1307.2 & 1505.2 & 1708.8 \\
Chhattisgarh & 800.0 & 895.5 & 1045.8 & 1204.1 & 1367.1 \\
East Uttar Pradesh & 706.9 & 791.3 & 924.1 & 1064.0 & 1208.0 \\
Jharkhand & 771.4 & 863.5 & 1008.4 & 1161.1 & 1318.2 \\
Odisha & 586.2 & 656.2 & 766.3 & 882.3 & 1001.7 \\
West Bengal & 1158.7 & 1166.7 & 1177.7 & 1187.7 & 1196.7 \\
\hline Eastern India & 823.9 & 925.2 & 1065.3 & 1080.5 & 1412.4 \\
\hline
\end{tabular}




\subsection{Oilseeds Scenario during 2050-51}

The most likely scenario of oilseed during 2050-51 with reference to eastern region were presented in table 5 and 6 and is compared with the National context during 2050-51, eastern region will be the habitant of 596.18 Million heads. Production of oilseed could be boosted with triple approach with improving productivity from currently (823.9) to $1412.4(\mathrm{~kg} / \mathrm{ha})$ during 2050 . This can be easily achieved in stipulated course of time with systematic approach and technological advancement. Secondly very limited scope is available for horizontal expansion only $0.423 \mathrm{Mha}$ is possible whereas atnational level scope is much wider to the extent possible of 6.68 Mha (Chand, 2009; Chand \& Singh, 2012). There is very good scope of utilization of supplementary sources of vegetable oils. Nonconventional sources of vegetable oils like Jatropha, mango kernel, neem, karanj, mahua, kusum, could be further stepped up, given their tremendous potential. Interestingly oil seeds production touchdown to record production (2.12 Mt) (Hegde, 2009; Hegde, 2012). Though the deficit (18.9 Mt) will increase with decreasing rate is very encouraging sign. Further Area production and productivity of both the crop commodity, sustainability a long cherished dream will be realized at all India level as this is region is engaged for sustainable food grain productionepically cereals that to be rice and wheat. Most importantly, at all India level forecast for oilseed sector are very encouraging. Moreover this region striving hard to sustain their oilseeds requirement but as a nation we will we self-reline country from net importer to net exporter as our estimated production touchdown all time high $(66.35 \mathrm{Mt})$ as against our requirements $(59.40 \mathrm{Mt})$ with surplus out production of $6.95 \mathrm{Mt}$.

Table 6. Projected oilseeds area, production, productivity and import scenario in eastern India during 2050-51

\begin{tabular}{lccccccc}
\hline States & Population (M) & $\begin{array}{c}\text { Additional } \\
\text { Area } \\
(\mathrm{Mha})\end{array}$ & $\begin{array}{c}\text { Total } \\
\text { Area } \\
(\mathrm{Mha})\end{array}$ & $\begin{array}{c}\text { Production } \\
(\mathrm{Mt})\end{array}$ & $\begin{array}{c}\text { Productivity } \\
(\mathrm{kg} / \mathrm{ha})\end{array}$ & $\begin{array}{c}\text { Requirement } \\
(\mathrm{Mt})\end{array}$ & $\begin{array}{c}\text { Import } \\
(\mathrm{Mt})\end{array}$ \\
\hline Assam & 43.26 & 0.06 & 0.34 & 0.29 & 854.4 & 1.52 & 1.23 \\
Bihar & 144.39 & 0.03 & 0.17 & 0.29 & 1708.8 & 5.09 & 4.8 \\
Chhattisgarh & 35.47 & 0.02 & 0.12 & 0.16 & 1367.1 & 1.25 & 1.09 \\
$\begin{array}{l}\text { East Uttar } \\
\text { Pradesh }\end{array}$ & 142.02 & 0.12 & 0.70 & 0.85 & 1208.0 & 5.01 & 4.16 \\
Jharkhand & 45.76 & 0.003 & 0.01 & 0.01 & 1318.2 & 1.61 & 1.60 \\
Odisha & 58.28 & 0.06 & 0.35 & 0.35 & 1001.7 & 2.05 & 1.70 \\
West Bengal & 127.00 & 0.13 & 0.76 & 0.91 & 1196.7 & 4.48 & 3.57 \\
Eastern India & 596.18 & 0.423 & 2.45 & 2.12 & 1412.4 & 21.02 & 18.90 \\
All India & 1685.21 & 6.68 & 33.5 & 66.35 & 1980.5 & 59.40 & 6.95 \\
\hline
\end{tabular}

Compound area expansion@0.5\% per year

\subsection{Pulses}

Time series data at all India is presented in table 6 showing decadal growth dynamics in respect to pulses, since 1950-51, also provides glimpses of success story of pulses production (Reddy 2004; GoI, 2012). Area production and productivity were registers incremental growth with the time at all India levels, though fluctuations were noticed in case of all the parameters. At All Indian levels remarkable, 30 per cent, growth in area under pulses (23.50 Mha) was notice during 2010-11.

Table 7. All-India area, production and productivity of pulses

\begin{tabular}{cccc}
\hline Year & Area (Mha) & Production $(\mathrm{Mt})$ & Productivity $(\mathrm{Kg} / \mathrm{ha})$ \\
\hline $1950-51$ & 19.09 & 8.41 & 441 \\
$1960-61$ & 23.56 & 12.70 & 539 \\
$1970-71$ & 22.02 & 11.69 & 531 \\
$1980-81$ & 22.46 & 10.63 & 473 \\
$1990-91$ & 24.66 & 14.26 & 578 \\
$2000-01$ & 20.35 & 11.08 & 544 \\
$2010-11$ & 23.50 & 14.60 & 689 \\
\hline
\end{tabular}

Source: Department of Agriculture and Cooperation, Ministry of Agriculture, Govt. of India 
During 2010-11, eastern region required 7.04 Mt of pulses but anyhow manage to produced 2.73 Mt only (Table 8), leaving rest to supply through internal management or through import. The requirement of grain legume/ pulses was calculated $14.6 \mathrm{~kg} /$ person/year + @12.5\%, for seed feed and wastage (Reddy, 2009). It is noticed that except Chhattisgarh none of the states including Eastern Uttar Pradesh failed grossly to fulfil their pulses requirements. It is worth to notice that India had to import 3.73 Mt of pulses during the corresponding financial year where as eastern region it required 3.59 Mt. This clearly indicates the urgency of revisiting the policy and planning should be tailored accordingly.

Table 8: Pulses, area, production, productivity and import status in eastern India during 2010-11

\begin{tabular}{|c|c|c|c|c|c|c|}
\hline States & Population (M) & Area (Mha) & Production (Mt) & Productivity $(\mathrm{kg} / \mathrm{ha})$ & Requirement (Mt) & Import (Mt) \\
\hline Assam & 31.1 & 0.05 & 0.04 & 800 & 0.49 & 0.45 \\
\hline Bihar & 103.8 & 0.56 & 0.47 & 839 & 1.62 & 1.15 \\
\hline Chhattisgarh & 25.5 & 0.81 & 0.49 & 605 & 0.40 & -0.09 \\
\hline East Uttar Pradesh & 80.9 & 1.27 & 1 & 787 & 1.26 & 0.26 \\
\hline Jharkhand & 32.9 & 0.32 & 0.22 & 688 & 0.51 & 0.29 \\
\hline Odisha & 41.9 & 0.87 & 0.4 & 460 & 0.65 & 0.25 \\
\hline West Bengal & 91.3 & 0.18 & 0.15 & 833 & 1.42 & 1.27 \\
\hline Eastern India & 407.4 & 4.06 & 2.77 & 681 & 6.36 & 3.59 \\
\hline All India & 1175 & 23.50 & 14.60 & 689 & 18.33 & 3.73 \\
\hline
\end{tabular}

Source: Department of Agriculture and Cooperation, Ministry of Agriculture, Govt. of India

\subsection{Decadal Growth Expected in Pulses (2010-11 to 2050-51)}

Data presented in table 9, with respect to decadal growth predictable for pulses. Emphasis has been given only for productivity, obviously because of well documented fact that not much scope of is exist to area expansion in this region, leaving all hope to improving productivity mandatory due to better agronomic management and technological advancement (GoI, 2012; Singh et al., 2012; Reddy, 2009). Pulses productivity scenario has been forecasted for individual states as well as eastern India as whole. During 2050-51, Bihar will be the leader productivity term $(1461.3 \mathrm{~kg} / \mathrm{ha})$. Odisha will be the laggard one with less than a ton productivity $(800.5 \mathrm{~kg} / \mathrm{ha})$.

Table 9. Projected decadal growth in pulses productivity $(\mathrm{kg} / \mathrm{ha})$ in eastern India

\begin{tabular}{lccccc}
\hline \multirow{2}{*}{ Years } & \multicolumn{5}{c}{ Pulses productivity (kg/ha) } \\
\cline { 2 - 5 } & $2010-11$ & $2020-21$ & $2030-31$ & $2040-41$ & $2050-51$ \\
\hline Assam & 800.0 & 912.3 & 1055.6 & 1221.5 & 1392.9 \\
Bihar & 839.3 & 957.1 & 1107.5 & 1281.5 & 1461.3 \\
Chhattisgarh & 604.9 & 689.8 & 798.2 & 923.6 & 1053.3 \\
East Uttar Pradesh & 787.4 & 897.9 & 1039.0 & 1202.2 & 1371.0 \\
Jharkhand & 687.5 & 784.0 & 907.2 & 1049.7 & 1197.0 \\
Odisha & 459.8 & 524.3 & 606.7 & 702.0 & 800.5 \\
West Bengal & 833.3 & 950.3 & 1099.6 & 1272.4 & 1450.9 \\
Eastern India & 680.8 & 787.8 & 911.5 & 1054.7 & 1185.4 \\
\hline
\end{tabular}

\subsection{Pulses Scenario during 2050-51}

The comprehensive possible scenario with reference to pulses and in eastern region in 2050 has been presented in table 9 and 10 is linked with National outline for same period. It was estimated that during 2050, with best possible effort, region will produce 4.84 Mt pulses with deficit of 9.79 Mt (Nadarajan \& Gupta, 2010). However, 
productivity of region will increase from present $(681 \mathrm{~kg} / \mathrm{ha})$ to $1185.4 \mathrm{~kg} / \mathrm{ha}$ and will surpass the then national average (979.6 Kg/ha). During 2050, India will be importing less (1.62 Mt) what we are importing currently (2.83 Mt) (GoI, 2012). Projections clearly indicate that Bihar will be the leading states among the eastern state in pulses productivity front with $(1461.3 \mathrm{~kg} / \mathrm{ha})$ during 2050 . Odisha may prove sluggish $(800.5 \mathrm{~kg} / \mathrm{ha})$ among the seven states of this regions. It is but obvious to improve productivity from 689 to $1185 \mathrm{~kg} / \mathrm{ha}$ through existing and new technologies, institutional support (Joshi, 2009). Introduction and strengthening of minor legumes like faba bean and cowpea and summer mungbean in irrigated parts hold promise to diversify the pulse productions. Apart from scaling up of productivity bringing additional $0.423 \mathrm{M}$ ha area under pulses production. Cropping system manipulation, crop diversification and multiple cropping systems is main feature to support crop diversifications. Intercropping of short-duration pulses one of the potential niche need to fully explore (Reddy, 2009). Minimizing post-harvest losses could save up to $0.15 \mathrm{Mt}$ losses in production, custom-hiring of machines for harvesting and threshing. Infrastructure support for processing and storage are steps needed to be strengthened (Joshi, 2009; Reddy, 2009).

Table 10. Projected pulses area, production, productivity and import scenario in eastern India during 2050

\begin{tabular}{|c|c|c|c|c|c|c|c|c|}
\hline States & Population (M) & $\begin{array}{l}\text { Additional } \\
\text { Area (Mha) }\end{array}$ & $\begin{array}{l}\text { Total } \\
\text { Area } \\
\text { (Mha) }\end{array}$ & $\begin{array}{l}\text { Production } \\
\text { (Mt) }\end{array}$ & $\begin{array}{c}\text { Productivity } \\
\qquad(\mathrm{kg} / \mathrm{ha})\end{array}$ & $\begin{array}{c}\text { Requirement } \\
\text { (Mt) }\end{array}$ & $\begin{array}{c}\text { Import } \\
(\mathrm{Mt})\end{array}$ & \\
\hline Assam & 43.26 & 0.001 & 0.051 & 0.07 & 1392.9 & 0.71 & 0.64 & \\
\hline Bihar & 144.39 & 0.010 & 0.570 & 0.83 & 1461.3 & 2.37 & 1.54 & \\
\hline Chhattisgarh & 35.47 & 0.015 & 0.825 & 0.87 & 1053.3 & 0.58 & -0.29 & \\
\hline $\begin{array}{l}\text { East Uttar } \\
\text { Pradesh }\end{array}$ & 142.02 & 0.023 & 1.293 & 1.77 & 1371.0 & 2.33 & 0.56 & \\
\hline Jharkhand & 45.76 & 0.006 & 0.326 & 0.39 & 1197.0 & 0.75 & 0.36 & \\
\hline Odisha & 58.28 & 0.016 & 0.886 & 0.71 & 800.5 & 0.96 & 0.25 & \\
\hline West Bengal & 127.00 & 0.003 & 0.183 & 0.27 & 1450.9 & 2.09 & 1.82 & \\
\hline Eastern India & 596.18 & 0.072 & 4.082 & 4.84 & 1185.4 & 9.79 & 4.95 & \\
\hline All India & 1685.21 & 3.00 & 17.60 & 26.06 & 979.6 & 27.68 & & 1.62 \\
\hline
\end{tabular}

\subsection{Methodology for Achieving Projected Target for Pulses and Oilseed in 2050}

Good agronomic practices (GAP) their different components like upgraded cultivars having potential to perform better under change climate condition, ensuring optimum plant stand through adjustment in spacing and thinning, site specific nutrient management (SSNM), efficient weed management, protective irrigation need-based plant protection, etc. have profound influence on the productivity of different oilseed and pulses. The improved technology packages were also found to be economically attractive. Good agronomic practices (GAP) is key to realized improve production of oilseeds and pulses under changing climate scenario, which is going to be more pronounced during coming days. Since oil seeds and pulses were more prone to biotic pests, sustainable management these also hold the key to achieved target production (Singh et al., 2012a; Singh et al., 2012b). There is need to adopt the all the component of advocated technology as a unit not to choose few of them at will, whichwere leading to several complication soil health hazards and poor response of technology as compared to demonstrated through FLD etc. (Hegde, 2012; Reddy, 2009). Moreover adoption of numerous modules of technology was low, highlighting the necessity for better diffusion (Hegde, 2009; Joshi, 2009). For efficient and smooth realization of set goal steps as mentioned below may be taken on priority basis (1) Encouraging accelerated adoption of present technology for bridging the yield gap (2) pulses and oilseed grower are poorer among the poor farming community hence institutional support is inevitable, which not only boost seed replacement rate but quality production as well (3) there must be provision for life-saving irrigation in pulse and oilseed growing pockets on priority basis(4) Guaranteeing availability of critical inputs viz., seedfertilizer, pesticides (5) gradual mechanization for pulse and oilseeds production (6). Public-private partnership for sustaining chain of producer to consumer and to minimizing post-harvest losses due to better-quality machines for harvesting, threshing and more importantly (7) policy support for value chain for pulse and oilseeds. 


\section{Summary and Conclusion}

In our opinion, postulated in this paper, projection for 2050-51 is also not suggesting any marked improvement to fulfil its demands. Forgone discussion is clearly envisaged that eastern region states are much more deficient in the productions of both the non-food items i.e. oilseeds and pulsesto fulfil their own current requirements. This is high time to frame polices pro to oilseeds and pulses in general and with special focus to this region. Further, since agriculture is state subject, certainly, state government has to take lead to save their pride and dignity of individual states, because who knows during 2050-51, India as country will be self-sufficient in agriculture sector as, modernization will speed up during $12^{\text {th }}$ planning. Importantly the population is going to be stagnation sometime before 2050-51, as it was evident from gradually slowing down the fertility rates. During that time India will definite be going to surpass china in GDP terms to become world largest economy.

\section{References}

Chand, R. (2009). Demand for food grains during the 11 Plan and towards 2020. Policy Brief No. 28. National Centre for Agricultural Economics and Policy Research (pp. 1-4). New Delhi.

Chand, R., \& Singh, R. B. (20120). Major Issues in Agriculture Sector for the Twelfth Plan. NAAS News, 12(1), 6-11.

Economic Survey. (2011-2012). Statistical Appendix (1) National Income and Production ( Table 1.9 to 1.19) (pp. A14 to A24).

GoI. (2012). Data Base on Indian Agriculture, Department of Agriculture and Cooperation. Ministry of Agriculture, Retrieved from http://dacnet.nic.in

Hegde, D. M. (2009). Can India achieve self-reliance in vegetable oils? In National Symposium on Vegetable Oils Scenario: Approaches to Meet the Growing Demands (pp. 1-15). 29-31 January.

Hegde, D. M. (2012). Carrying capacity of Indian agriculture: oilseeds. Current Science, 102(6), 25867-25873.

Joshi, P K. (2009). Prices and Market Intervention in Pulses., paper presented in Brainstorming workshop on Issues and Strategies for Increasing Productivity and Production of Pulses in India, organised by the Indian Council of Agricultural Research and Ministry of Agriculture, Government of India, New Delhi, 9-10 June.

Nadarajan, N., \& Gupta. S. (2010). Scenario of pulses production in India. Agriwatch (pp.26-27). Narasinga Rao, B. S. 2010. Nutrient requirement and safe dietary intake for Indians. NFI Bull., 31, 1-8.

Reddy, A. A. (2009). Pulses Production Technology: Status and Way Forward. Economic \& Political Weekly, XLIV (52), 73-80.

Reddy, A. A. (2004). Consumption Pattern, Trade and Production Potential of Pulses. Economic \& Political Weekly, XL(48), 54-60.

Singh, A. K., Sangle, U. R., \& Bhatt, B. P. (2012a). Mitigation of imminent climate change and enhancement of agricultural system productivity through efficient carbon sequestration and improved production technologies. Indian Farming, 61(10), 5-9.

Singh, A. K., Singh, D., Singh, A. K., Gade, R. M., \& Sangle, U. R. (2012b). Good Agronomic Practices (GAP)-An efficient and eco-friendly tool for sustainable management of plant diseases under changing climate scenario. J. of Plant Disease Sci., 7(1), 1-8.

Singh, R. D., Dey, A., \& Singh, A. K. (2011). Vision -2030, ICAR Research Complex for Eastern Region Patna (p. 28). Ministry of Agriculture, Govt. of India. Retrieved from www.Indiastat.com/ 